\title{
Is the painted frog Discoglossus pictus a declining species in Italy? On the reliability of a distributional atlas approach
}

\author{
Francesco Lillo, Francesco Paolo Faraone, Mario Lo Valvo*
}

\begin{abstract}
The conservation status of amphibians is often assessed using public databases because of a lack of up-to-date field data. However, it is crucial that this kind of data is used carefully, evaluating the reliability and the consistency of the information. In Italy, the conservation status of the painted frog, Discoglossus pictus, was recently assessed using public databases, and the outcome highlighted a worrying situation for the species. We analyzed the reliability of these conclusions and reassessed the status of the painted frog, taking into account its insular distribution and new data of species occurrence. Our results contrast with the previous analysis and show how an incautious use of public databases can lead to inaccurate assessment of the amphibian conservation status.
\end{abstract}

Keywords: amphibian conservation, amphibian decline, Discoglossus pictus, distribution atlas, Sicily.

Monitoring changes in species distribution and abundance is fundamental to understand the consequences of human actions and formulate wildlife management strategies. Atlas data are often used by conservation biologists as an important resource to assess the conservation status of endangered species (Denoël, 2012). The information in national and regional atlases represents an important dataset for species distribution models (Elphick, 1997; Donald and Fuller, 1998; Rondinini et al., 2006; Botts et al., 2011).

The conservation status of amphibian species is often assessed by analyzing public databases because of the lack of up-to-date field data (Botts et al., 2011). However, it is crucial that this kind of data is used carefully, and the reliability and consistency of the information evaluated. Atlas databases combine information from researchers and volunteers. Often, only presence-only data are recorded, providing information about species distribution and changes in species distribution. Changes in distribution are often viewed as surrogate measures of changes in abundance (Kéry et al., 2010). However, a change in abundance does not nec-

Dipartimento di Scienze e Tecnologie Biologiche, Chimiche e Farmaceutiche, Università di Palermo, Via Archirafi 18, 90123 Palermo, Italy

*Corresponding author; e-mail: mario.lovalvo@unipa.it essarily lead to a change in distribution. Thus, a decline reported for a species with a small distribution or in a small part of a large distribution area, may be over- or underestimated in its severity (Skelly et al., 2003).

In this context, our study focused on the conservation status of the painted frog, Discoglossus pictus, in Italy. The painted frog is a Mediterranean anuran amphibian with a natural distribution on the western Maghreb coast (Tunisia and Algeria) and the main islands of the Siculo-Maltese archipelago. Although the species is able to breed in many kinds of habitat, the adults are quite elusive and male vocalizations fairly weak (Capula, 2007). This elusiveness may lead to underestimation of the painted frog distribution within a geographical region.

The recent literature described the Italian painted frog population as being in worrying decline: the WWF Red Book of Italian fauna (Bulgarini et al., 1998) considered the painted frog "Near Threatened" (applying IUCN criteria). In Sicily, Turrisi and Vaccaro (1998) considered the species to be in "progressive reduction" due to changes in farming practices; Di Palma et al. (2001) asserted that the "painted frog has shown a significant decline in recent decades"; Lo Valvo and Longo (2001) considered the Sicilian population to be "significantly decreased". Capula et al. (2005) con- 
firmed the status as "Near Threatened". Capula (2006, 2007) defined the painted frog to be "in progressive and alarming decline in the whole of Sicily". Turrisi (2008) asserted that the Sicilian and Maltese populations "deserve appropriate protection measures". Capula (2009) sustained that "in Italy, the painted frog has undergone a remarkable and alarming decrease in recent decades".

In some areas of Sicily, there is evidence for decreasing populations due to the loss of breeding sites in peri-urban areas (Di Palma et al., 2001) and the recent introduction of the invasive amphibian Xenopus laevis (Lillo et al., 2011).

Recent studies applying quantitative and statistical approaches have contributed to the increasing concern about the conservation status of the painted frog. Andreone and Luiselli (2000) applied a statistical analysis based on occurrence data from the Societas Herpetologica Italica database (SHI, 1996), concluding that the painted frog is in need of urgent conservation action in Italy, especially considering its status of insularity. More recently, using the Italian database CKmap 5.3.8 (Ruffo and Stoch, 2005), D'Amen and Bombi (2009) (hereafter DB 2009), assessed its status in Italy and declared the painted frog to be suffering from the third most severe decline after Pelobates fuscus and Bombina pachypus.

The more general conservation state of the painted frog does not appear to be alarming: the IUCN conservation assessment (Bosch et al., 2009) categorized the species' status as being of "Least Concern", the lowest possible level of threat. While the species is not threatened globally, it is possible that the painted frog is undergoing a worrying decline on a regional scale.

Our aim was thus to clarify whether the decline in the painted frog observed in Italy is of real concern, or whether it is overestimated compared to the rest of its natural distribution range. The choice of appropriate local conservation measures and tools also depends on a solid understanding of this scenario. We also evaluated how the use of an incomplete database, or the inappropriate analysis of a species with a limited geographical distribution, can lead to inaccurate assessment. We chose to use the same method as DB 2009 and fitted the original data to the geographical region where the painted frog is present. DB 2009 used CKmap 5.3.8 (Ruffo and Stoch, 2005) as public database for the current and past occurrence of Italian amphibian species.

The CKmap is considered to be the largest, most authoritative and up-to-date faunal information source in Italy. It is composed of more than 500000 records of approximately 10000 terrestrial and freshwater species (Ruffo and Stoch, 2005). The database contains occurrence information for a UTM grid square of $10 \times$ $10 \mathrm{~km}$. For each cell species occurrence and year of last observation (YLO) is recorded. DB 2009 defined a threshold year and categorized as 'DECLINE' each cell in which the YLO was before the threshold year and 'STABLE', each cell with a YLO after this threshold. Based on the frequency distribution of the observations (fig. 1a), DB 2009 chose a threshold of between 1985 and 1986, as it was before the peak in knowledge of the 1990s, and was followed by substantial survey work. We can thus assume that each square had multiple surveys after the threshold. All cells with no amphibian records after the threshold were excluded from the statistical analysis. This precautionary approach reduced the risk of bias due to the absence of recent monitoring in the cell. The assumption is that, if a species was recorded in a cell before the threshold (and the cell was surveyed after the threshold), the species is probably extinct in the cell. The species decline was calculated as the ratio between the number of cells in which a species is categorised as DECLINE and the total number of cells where the species was recorded (DECLINE + STABLE).

To reassess the conservation status of the painted frog, we conducted three analyses. First, we assessed whether the threshold year se- 


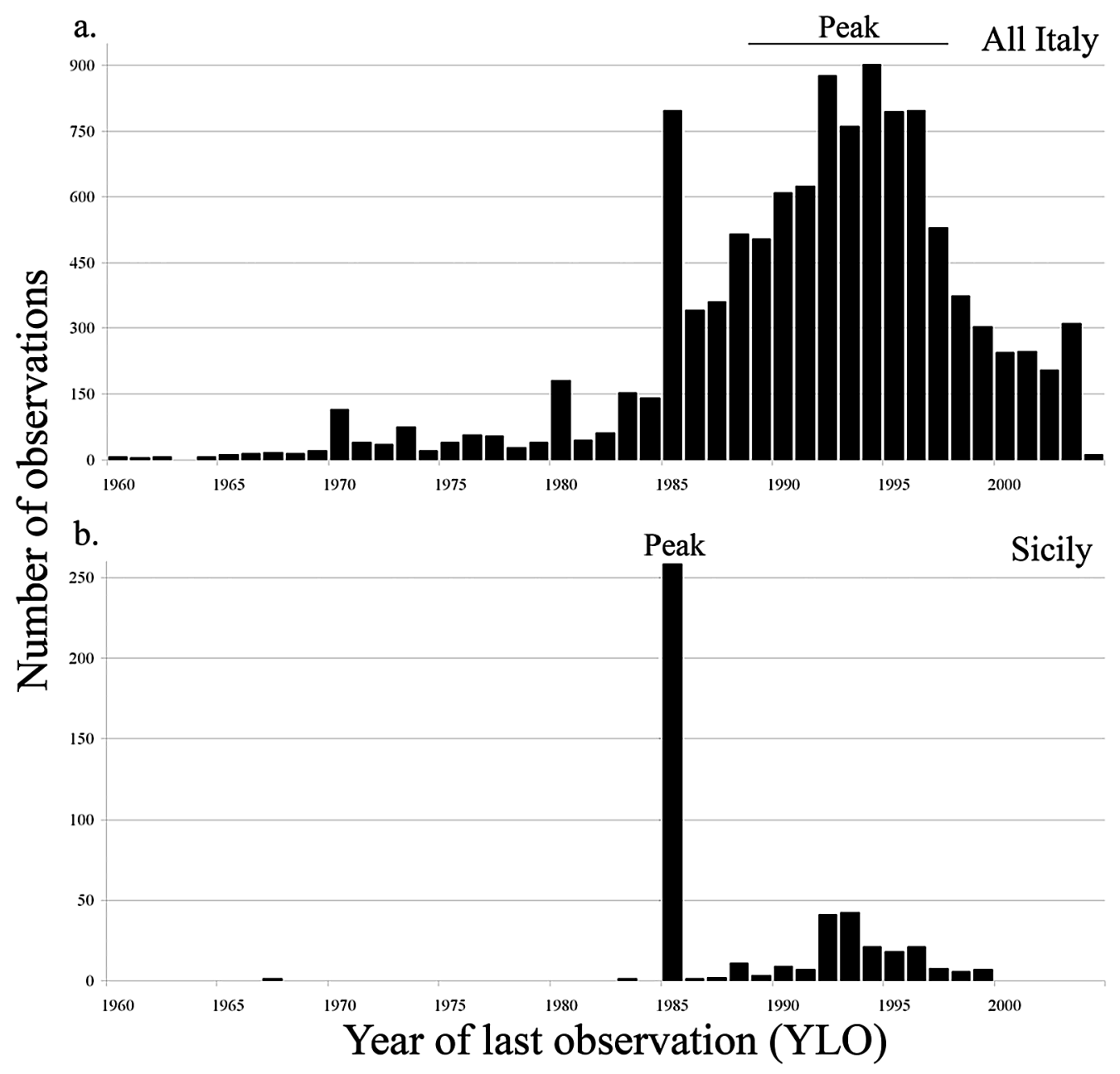

Figure 1. Distribution of Year of last observation in the amphibian CKmap database for the whole Italy of (a) and Sicily (b).

lected by DB 2009 is appropriate for the painted frog. Second, to reassess the painted frog decline, we added to the CKmap dataset our field data of painted frog occurrence, collected between 2008 and 2012, together with information from recently published literature (Giacobbe and Restivo, 2010; Restivo et al., 2010). Third, we assessed how the rate of decline depends on the threshold year.

In Italy, painted frog distribution is restricted to Sicily and for this reason, in contrast with DB 2009, we preferred to separate the Sicilian CKmap data from those of the rest of Italy. This methodology allowed us to assess the suitability of the threshold selected by DB 2009 (for all the Italian amphibian fauna) for Sicily. The driving concepts of this procedure were a) discrepancy in data collecting methods between Sicily and Italy (i.e. differences in the timing of data collection) can lead to inaccurate assessment: if data sets are merged, the differences may no longer be apparent; b) the choice of a non-appropriate threshold can lead to important differences in the assessment of local data (i.e. Sicilian data and painted frog). To evaluate the suitability of the DB 2009 threshold for the Sicilian data, we compared the whole dataset of the amphibian YLO with the Sicilian data. This comparison allowed us to propose an alternative threshold. 
Our field data on occurrence were collected between 2008 and 2012. We surveyed 117 randomly selected cells ( $40 \%$ of total cells) and during the reproductive period searched for the presence of adults, eggs and larvae. To assess how the rate of decline may depend on the threshold year selected, we estimated the decline rate of the painted frog for each year between 1983 and 1997 (the period of data occurrence for the species in the CKmap database). We report the trend in fig. 2.

The CKmap database shows that the peak in YLOs for all Italian amphibian species was during the 1990s (fig. 1a). A total of 2288 YLOs were recorded between 1780 and 1985, while between 1986 and 2004 the number of YLOs was 9310 (80.3\%). Analyzing only the Sicilian data, we observed that the data from the year 1985 represented the peak in Sicilian YLOs, with $56.2 \%$ of all YLOs (fig. 1b). The threshold selected by DB 2009 (1985-1986) could therefore be considered inappropriate for the Sicilian data, as it was after the peak in observations. Hence, we propose a more appropriate threshold between the years 1984 and 1985. In fact, the decline rate showed an abrupt increase between 1984 and 1985 relating to the peak in observations recorded in 1985 (fig. 2). Furthermore, considering that 1985 was the year of peak observations in Sicily, it was not possible to select a threshold subsequent to 1984 .

In our field surveys we detected the presence of painted frog in 107 out of 117 cells surveyed. Among these, 96 cells were new records or cells with YLO previous to the selected threshold. Moreover, we attributed 6 new presences based on the recent literature (Giacobbe and Restivo, 2010; Restivo et al., 2010).

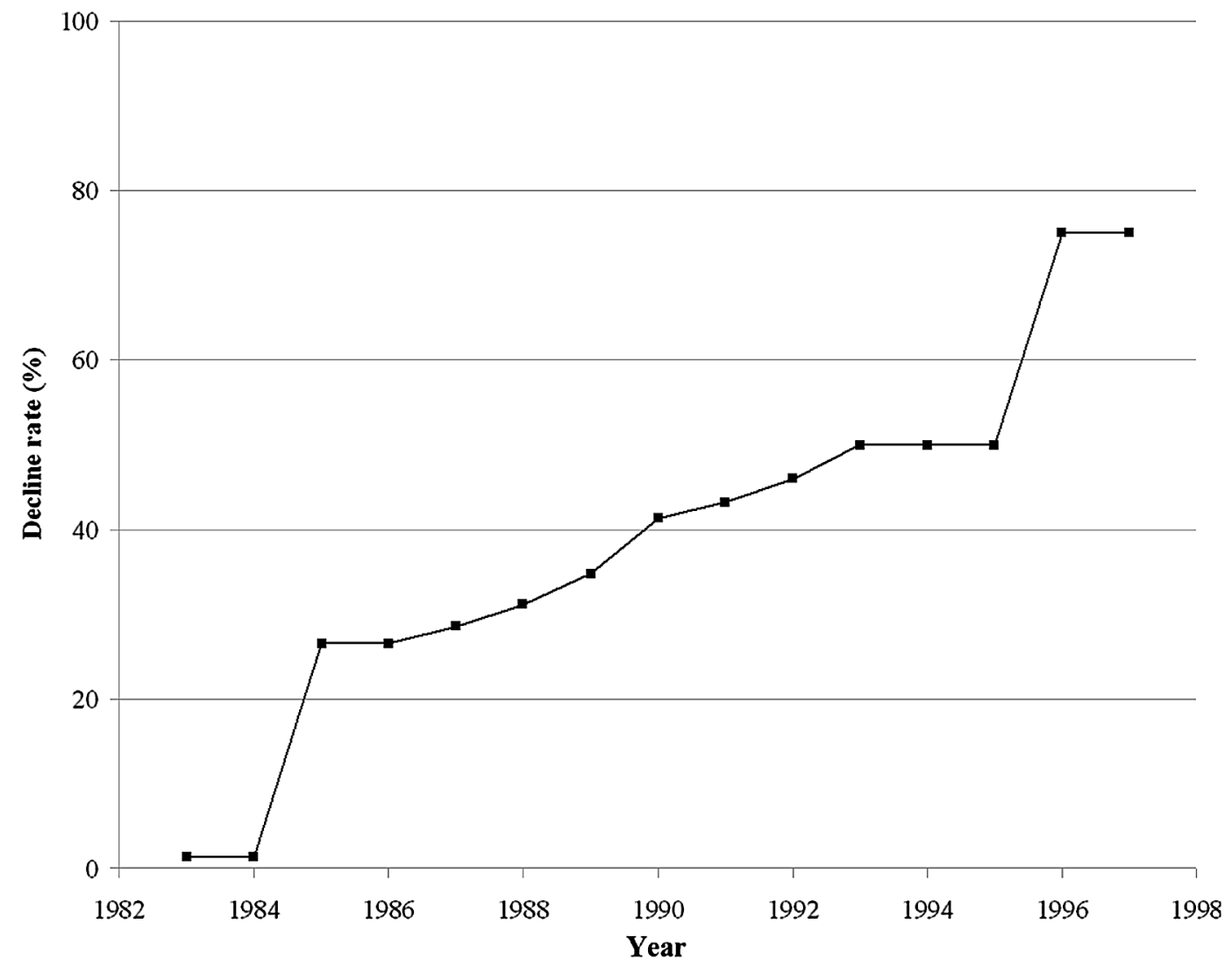

Figure 2. Variation in the estimated decline of Discoglossus pictus as a function of threshold year (from 1983 to 1998). 
We recalculated the painted frog decline rate to assess how the use of new field data, a different threshold and the combined effects of both (table 1) changes the perception of the painted frog's conservation state in Italy. Applying the new threshold, we observed a decrease in the decline of $95.9 \%$ for a single year of difference (from $32.1 \%$ to $1.3 \%$ ). Adding the new data we recorded an increased number of STABLE cells from 36 to $138(+383.3 \%)$ (fig. 3$)$. The painted frog decline rate decreased by $85.0 \%$, from $32.1 \%$ to $4.8 \%$. Lastly, the combined effect of new data and new threshold showed a decrease in the painted frog decline rate of $97.8 \%$, from $32.1 \%$ to $0.7 \%$. Each of the three estimates gave a much lower decline rate than those of all

Table 1. Estimate of decline rate of Discoglossus pictus in Italy according to different factors (Old data: only CKmap database; Up-to-date data: CKmap database + literature data + field data).

\begin{tabular}{lcc}
\hline & $\begin{array}{c}\text { Old threshold } \\
(1985-86)\end{array}$ & $\begin{array}{c}\text { New threshold } \\
(1984-85)\end{array}$ \\
\hline Old data & $32.1 \%$ & $1.3 \%$ \\
Up-to-date data & $4.8 \%$ & $0.7 \%$ \\
\hline
\end{tabular}

the other Italian species evaluated by DB 2009 (lowest value: Pelophylax spp. $=12.2 \%$ ).

Our results on the conservation assessment of the painted frog are in contrast with previous analyses made using public datasets (Andreone and Luiselli, 2000; DB 2009). The new outcomes suggest a much lower rate of decline in the Italian distribution of this species. The recalculated decline ratios are much lower than in all the other Italian species assessed by DB 2009. Conversely, the updating and optimizing of CKmap data depicts a situation that agrees with the IUCN assessment for the whole distribution area of this species (Bosch et al., 2009), highlighting a low level of risk also in Italy.

Our analysis shows how an incautious use of public databases, which do not take into account the differences in data distribution between different geographical regions and species, can lead to an unreliable assessment of amphibian conservation status. Results suggest that the CKmap amphibian database was compiled with data collected using different sampling methods for different geographical regions (at least be-

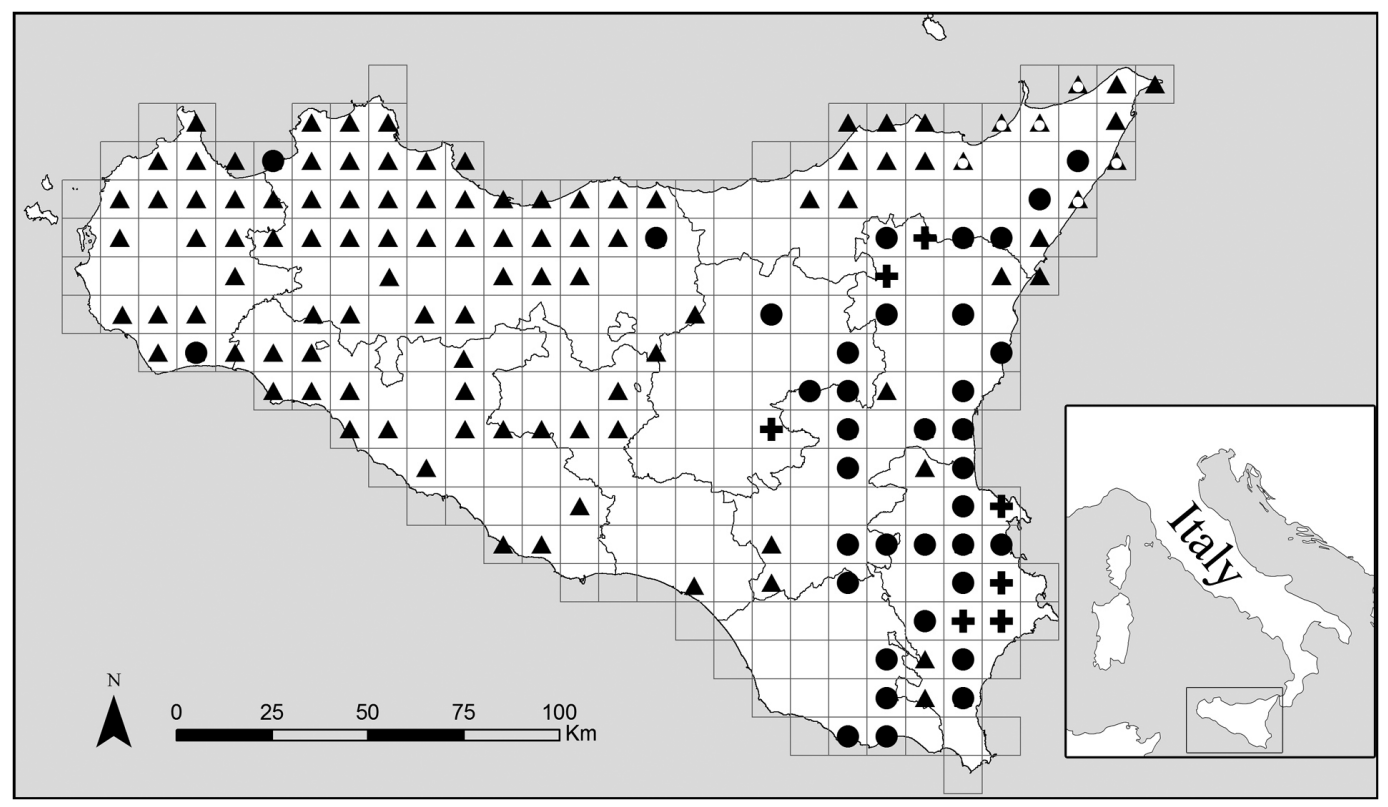

Figure 3. Italian distribution of Discoglossus pictus. Circles: occurrence confirmed after 1985 using CKmap database. Triangles: original new occurrence data (2008-2012). Triangles with white circle: recently published presence data (2010). Crosses: unconfirmed historical occurrence using CKmap database (before 1985). 
tween Sicily and the rest of Italy). As shown in fig. 1, differences in the timing of data collection between Sicily and the whole of Italy could lead to the selection of an inappropriate threshold. In this case, the overestimated decline rate would reinforced because the insularity of the painted frog.

The risk of over- or underestimating a decline is higher in a species with limited or insular distribution because each data (e.g. of presence) has a greater relative importance in a smaller database, and could affect the final assessment. In species from non-insular and large distribution areas, biases or local differences can be diluted in a large dataset. For example, applying the same shift in the threshold of one year, from 1985 to 1984 (as proposed for the painted frog), the decline rate for Pelobates fuscus (the species most in decline, according to DB 2009) decreases from $54.4 \%$ to $50.0 \%$, and that for Bombina pachypus (the second most-declining species in Italy) decreases from $37.5 \%$ to $30.1 \%$. In both cases, applying the IUCN criteria (IUCN, 2001), the assessment of conservation status remains the same: "Endangered" for Pelobates fuscus and "Vulnerable" for Bombina pachypus. Conversely, applying the same criteria to the painted frog, its conservation status shifts from "Vulnerable" to "Least Concern".

We suggest that assessment of conservation status using only public databases could be improved by involving an expert panel. Key information and up-to-date distribution data on the focal species and geographical areas could then be added, and the reliability and analysis of the data reviewed. We propose that grouping species with a large or small scale of distribution together in a single assessment is not appropriate. To assess "insular" species we suggest that an exhaustive approach should not be based exclusively on presence/absence cells of $10 \mathrm{~km}$ each side. In order to record the temporal persistence of a population viability, a careful analysis, in mid-term studies, should be based on repeated sampling of a representative num- ber of breeding sites, as recently proposed by SHI (2011).

Acknowledgements. Funding was provided by the "Dipartimento Interventi Strutturali per l'Agricoltura della Regione Siciliana" in the framework of the "Sviluppo di strumenti gestionali propedeutici alla pianificazione Faunisticovenatoria ed ambientale e alla Conservazione delle specie minacciate della Regione Siciliana" project. We thank Federico Marrone for his contribution to field data collection. We also wish to acknowledge the helpful comments of Benedikt Schmidt, Sebastiano Salvidio and two anonymous reviewers.

\section{References}

Andreone, F., Luiselli, L. (2000): The Italian batrachofauna and its conservation status: a statistical assessment. Biol. Conserv. 96: 197-208.

Bosch, J., Andreone, F., Tejedo, M., Donaire-Barroso, D., Lizana, M., Martínez-Solano, I., Salvador, A., GarcíaParís, M., Gil, E.R., Slimani, T., El Mouden, H., Joger, U., Geniez, P., Corti, C. (2009): Discoglossus pictus. In: IUCN 2011. IUCN Red List of Threatened Species. Version 2011.2. www.iucnredlist.org. Downloaded on 07 February 2012.

Botts, E.A., Erasmus, B.F.N., Alexander, G.J. (2011): Geographic sampling bias in the South African Frog Atlas Project: implications for conservation planning. Biodivers. Conserv. 20: 119-139.

Bulgarini, F., Calvario, E., Fraticelli, F., Petretti, F., Sarrocco, S. (Eds) (1998): Libro Rosso degli Animali d'Italia - Vertebrati. WWF Italia, Roma.

Capula, M. (2006): Discoglossus pictus. In: Atlante degli Anfibi e dei Rettili d'Italia/Atlas of Italian Amphibians and Reptiles - Societas Herpetologica Italica. Sindaco, R., Doria, G., Razzetti, E., Bernini, F., Eds, Polistampa, Firenze.

Capula, M. (2007): Discoglossus pictus Otth, 1837. In: Fauna d'Italia. Amphibia. Lanza, B., Andreone, F., Bologna, M.A., Corti, C., Razzetti, E., Eds, Calderini, Bologna.

Capula, M. (2009): Discoglossus pictus Otth, 1837. In: Anfibi d'Italia. Quaderni di Conservazione della Natura, Vol. 29. Lanza, B., Nistri, A., Vanni, S., Ministero dell'Ambiente e della Tutela del Territorio e del Mare, ISPRA, Grandi \& Grandi Editori.

Capula, M., Ceccarelli, A., Luiselli, L. (2005): Amphibians of Italy: a revised checklist. Aldrovrandia 1: 103-110.

Denoël, M. (2012): Newt decline in Western Europe: highlights for relative distribution change within guild. Biolo. Conserv. 21: 2887-2898.

Donald, P.F., Fuller, R.J. (1998): Ornithological atlas data: a review of uses and limitations. Bird Study 45: 129-145.

D’Amen, M., Bombi, P. (2009): Global warming and biodiversity: Evidence of climate-linked amphibian declines in Italy. Biol. Conserv. 142: 3060-3067. 
Di Palma, M.G., Riggio, S., Russo, G., Violani, C., Zava, B. (2001): Il Discoglosso (Discoglossus pictus Otth, 1837) nella Conca D'oro (Palermo). Rivista di Idrobiologia 40: 263-269.

Elphick, C.S. (1997): Correcting avian richness estimates for unequal sample effort in atlas studies. Ibis 139: 189190.

Giacobbe, D., Restivo, S. (2010): Distribuzione dell'erpetofauna nel Parco fluviale dell'Alcantara e nei corsi d'acqua che vi confluiscono. In: Atti del VII Congresso Nazionale Societas Herpetologica Italica. Di Tizio, L., Di Cerbo, A., Di Francesco, N., Cameli, A., Eds, Ianieri Edizioni, Pescara.

IUCN (2001): Category \& Criteria (version 3.1). IUCN Species Survival Commission (http://www.iucnredlist. org/static/categories_criteria_3_1)

Kéry, M., Royle, A., Schmid, H., Schaub, M., Volet, B., Häfliger, G., Zbinden, N. (2010): Site-occupancy distribution modeling to correct population-trend estimates derived from opportunistic observations. Conserv. Biol. 24: 1388-1397.

Lillo, F., Faraone, F.P., Lo Valvo, M. (2011): Can the introduction of Xenopus laevis affect native amphibian populations? The effects of a biological invasion. Biol. Invasions 13: 1533-1541.

Lo Valvo, F., Longo, A.M. (2001): Anfibi e rettili di Sicilia. Doramarkus, WWF. Palermo.

Restivo, S., Giacobbe, D., Lo Paro, G. (2010): Nuovi rilevamenti sull'erpetofauna dell' area peloritana (Sicilia nordorientale). Atti Soc. italiana Sci. Nat. Museo Civico Storia Naturale Milano 151: 77-97.
Rondinini, C., Wilson, K.A., Boitani, L., Grantham, H., Possingham, H.P. (2006): Tradeoffs of different types of species occurrence data for use in systematic conservation planning. Ecol. Lett. 9: 1136-1145.

Ruffo, S., Stoch, F. (Eds) (2005): Checklist e distribuzione della fauna italiana. Memorie del Museo Civico di Storia Naturale di Verona 16: 1-307.

SHI (1996): Atlante provvisorio degli Anfibi e Rettili italiani. Annali del Museo Civico di Storia Naturale "G. Doria" 91: 95-178.

SHI (2011): Assessing the status of amphibian breeding sites in Italy: a national survey. Acta Herpetol. 6: 119126.

Skelly, D.K., Yurewicz, K.L., Werner, E.E., Relyea, R.A. (2003): Estimating decline and distributional change in Amphibians. Conserv. Biol. 17: 744-751.

Turrisi, G.F., Vaccaro, A. (1998): Contributo alla conoscenza degli anfibi e rettili di Sicilia. Bollettino dell'Accademia Gioenia Scienze Naturali Catania 30: 588.

Turrisi, G.F. (2008): Discoglosso dipinto Discoglossus pictus pictus, Otth, 1837. In: AAVV: Atlante della Biodiversità della Sicilia: Vertebrati terrestri. Studi e Ricerche, 6, Arpa Sicilia, Palermo.

Submitted: May 18, 2012. Final revision received: February 28, 2013. Accepted: March 10, 2013.

Associated Editor: Benedikt Schmidt. 